\section{Deaths of bicycle riders in Brazil: characteristics and trends during the period of $2000-2010$}

\section{Mortalidade de ciclistas no Brasil: características e tendências no período $2000-2010$}

\section{Leila Posenato Garcia'}

\section{Lúcia Rolim Santana de Freitas"}

Elisabeth Carmen Duarte"

'Instituto for Applied Economic Research - Brasília (DF), Brazil.

"School of Medicine of Universidade de Brasília - Brasília (DF), Brazil.

\section{Abstract}

Introduction: In Brazil, bicycle use has been increasing. Accidents involving cyclists are important causes of morbidity and mortality. Objective: To describe the mortality of cyclists injured in transport accidents in Brazil, the characteristics of the victims and of the occurrence, and to investigate its trends during the period between 2000 and 2010. Methods: A descriptive study with data from the Mortality Information System (SIM) was conducted in the period of 2000 2010. Crude and age-standardized corrected mortality rates were calculated for Brazil, its macro-regions and states. Linear regression was used to study the trends. Results: In the period of 2000 - 2010, 32,422 bicycle-related deaths were identified in Brazil. In 2010, there were, on average, 8.8 bicycle-related deaths per day. Age-standardized mortality rates for the country were 15.3 and 15.9 deaths per million inhabitants in 2000 and 2010, respectively ( $\mathrm{p}=0.725)$. During the whole period, the Center-Western region showed the highest rates, though stable, corresponding to 23.4 deaths per million inhabitants in 2010. Men accounted for $85.4 \%$ of deaths, with death risk 5 times higher than women. Conclusion: In spite of the stable rates for the country, there was an increase trend in the Northern and Northeastern regions, while a decreasing trend was observed in the Southern and Southeastern regions. The risk of death was higher among men, elderly, and people living in large cities and at the Center-Western region.

Keywords: Epidemiology, descriptive. Temporal distribution. Mortality. Accidents. Traffic. External causes. Accident prevention. 


\section{Resumo}

Introdução: No Brasil, o uso da bicicleta tem sido crescente. Os acidentes envolvendo ciclistas são causas importantes de morbidade e mortalidade. Objetivo: Descrever a mortalidade de ciclistas traumatizados em acidentes de transporte, as características das vítimas e da ocorrência e investigar sua tendência no período 2000 - 2010. Métodos: Foi realizado estudo descritivo com dados do Sistema de Informações sobre Mortalidade (SIM) no período 2000 - 2010. Foram calculadas taxas de mortalidade específicas corrigidas brutas e padronizadas por idade, para o Brasil, regiões e Unidades da Federação, além da mortalidade proporcional. Regressão linear simples foi empregada para estudo das tendências. Resultados: No período 2000 - 2010, após correção, foram identificados 32.422 óbitos de ciclistas traumatizados em acidentes de transporte no Brasil. Em 2010, ocorreram em média 8,8 óbitos por dia. As taxas de mortalidade padronizadas para o país corresponderam a 15,3 e 15,9 óbitos de ciclistas por milhão de habitantes, em 2000 e 2010, respectivamente $(\mathrm{p}=0,725)$. Em todo o período, a região centro-oeste apresentou taxas estáveis e mais elevadas que as demais regiões, equivalente a 23,4 óbitos por milhão de habitantes, em 2010. Os homens representaram $85,4 \%$ dos óbitos, com risco de morte cinco vezes superior às mulheres. Conclusão: Apesar da estabilidade das taxas no país, houve tendência de aumento nas regiões nordeste e norte e redução no sul e sudeste. O risco de morte foi mais elevado entre homens, pessoas idosas e residentes em municípios de grande porte e na região centro-oeste.

Palavras-chave: Epidemiologia descritiva. Distribuição temporal. Mortalidade. Acidentes de trânsito. Causas externas. Prevenção de acidentes.

\section{Introduction}

The bicycle is a low cost mean of transport that also presents advantages to the environment, besides allying transport to the practice of physical activity for the rider. Brazil has the sixth largest bicycle fleet among all the countries in the world, losing to China, India, the United States, Japan and Germany ${ }^{1}$. The bicycle is the most used individual mean of transport in the country. In small urban centers (more than $90 \%$ of the Brazilian cities), bicycles also share space with pedestrians in most dislocations. This happens because bicycles are an economically accessible transportation alternative for most people, no matter the income, and they can be used from childhood to older ages ${ }^{1}$.

For those reasons, in Brazil there are initiatives to encourage the use of bicycles as a mean of transport, such as the Brazilian Program of Bicycle Mobility, or the Bicycle Brazil Program (PBB). This Program was established in 2004 after the initiative of the National Secretariat of Transport and Urban Mobility (SeMob), of the Ministry of Cities (MCidades) ${ }^{2}$, in order to stimulate municipal and state governments, as well as the Federal District, to develop and improve actions that favor the safer use of the bicycle as a mean of transport.

As a consequence, the use of the bicycle has been increasing in Brazil, both as a mean of transport to work and school, and to leisure activities. Even though it plays a relevant role in the dislocation of millions of people, the necessary infrastructure to the use of bicycles in the country is not available everywhere ${ }^{1}$. The shared traffic of bicycles and cars is pointed out as the main insecurity factor, facilitating the occurrence of accidents ${ }^{3}$.

Injuries caused by traffic accidents are an important cause of death in the world. Out of the approximate 1.3 million deaths caused by these injuries every year, nearly $90 \%$ take place in medium and low-income countries $^{4}$. In the region of the Americas, $39 \%$ of the people who die because of lesions caused by traffic are considered to be vulnerable: pedestrians, cyclists or motorcyclists. However, in the sub-region of the Southern 
Cone, where Brazil is located, mortality of vulnerable people reaches $50 \%$ of trafficrelated deaths ${ }^{5}$. In Brazil, mortality caused by transport accidents represented, in 2007, almost $30 \%$ of the total of deaths caused by external causes ${ }^{6}$. In 2003, out of the total of deaths by land transport accidents, $46.9 \%$ involved vulnerable people (3.8\% of cyclists, $30.2 \%$ of pedestrians and $12.9 \%$ of motorcyclists); and $30.2 \%$ involved car occupants ${ }^{7}$. In the comparison of proportional mortality according to mean of transport, it should be considered that, in major urban centers, where the number of deaths has greater impact on statistics, the bicycle is not so used, in contrast with the other means of transport. In fact, a study conducted in Porto Alegre, capital of the state of Rio Grande do Sul, revealed that the risk of death for those who use bicycles was about 80 times higher than for those using the collective transport. The same risk was 13 times higher when compared to bus users, but who walk part of the route ${ }^{3}$.

Transport accidents, including those involving bicycles, are important causes of morbidity and mortality and impose high costs to the Unified Health System (SUS), as well as to society ${ }^{8}$. To know about the mortality of cyclists who were injured in transport accidents, as well as the profile of the victims, provides subsidies to assist the elaboration and the implementation of public policies addressed to facing such a serious social and public health problem.

The objectives of this study are to describe the mortality of cyclists injured in transport accidents, including the characteristics of the victims and the circumstances of the accident, as well as to investigate its tendency in the period of $2000-2010$.

\section{Methods}

A descriptive study was conducted with data from the Mortality Information System (SIM) concerning the period of $2000-2010$, extracted in July, 2012.

The deaths of Cyclists Injured in Transport Accidents (CTAT) correspond to codes V10$\mathrm{V} 19$ of the tenth revision of the International
Classification of Diseases and Related Health Problems (ICD-10). The proportional mortality of CTAT in relation to the total of deaths caused by land transport accidents (LTA) was calculated by considering the deaths corresponding to the following codes in the tenth revision of ICD-10: V01-V09 (pedestrian injured in transport accident), V-20-V29 (motorcycle rider injured in transport accident), V-30-V39 (occupant of three-wheeled motor vehicle injured in transport accident), V40-V49 (car occupant injured in transport accident), V50V59 (occupant of pick-up truck or van injured in transport accident), V60-V69 (occupant of a heavy transport vehicle injured in transport accident), V70-V79 (bus occupant injured in transport accident), and V83-V87 (other land transport accidents).

Deaths of CTAT were described according to gender, color or ethnicity (less than 10, 10 to 19,20 to 29,30 to 39,40 to 49,50 to 59,60 to 69 , 70 years old or more), region of residency, day of the week and month of occurrence. The description was also made in relation to the size of the city, according to the classification adopted by the Brazilian Institute of Geography and Statistics (IBGE), as follows: (1) small $1=$ cities with up to 20,000 inhabitants, (2) small $2=$ cities with 20,001 to 50,000 inhabitants, (3) medium = cities with 50,001 to 100,000 inhabitants, (4) large = cities with 100,001 to 900,000 inhabitants and (5) metropolis = cities with more than 900,000 inhabitants.

The absolute number of deaths of CTAT, mortality and proportional mortality rates were calculated according to these variables for the triennium 2000 - 2002 and 2008 - 2010, as well as for the total period of $2000-2010$. In order to describe the deaths of CTAT, the correction for sub-register was made, with proportional redistribution of deaths by LTA; the type of vehicle or transport accident was not specified (ICD-10 causes V89-V99).

The risk of death of CTAT was estimated by the calculation of mortality rates per million inhabitants for Brazil, its regions and Federation Units (FU). The crude mortality rate of CTAT was calculated by dividing the corrected number of deaths, in a given place and period, by the population in the 
same place and period multiplying it by one million. The size of the resident population used as denominator came from census (2000 and 2010), and intercensal projections (2001 to 2009) produced by IBGE and made available by DATASUS. The mortality rates of CTAT standardized by age were calculated, using the standard population of the World Health Organization (WHO) ${ }^{9}$. The age groups defined for the standardization of the rates were: < 10, 10 to 19,20 to 29,30 to 39,40 to 49,50 to 59,60 to 69 , 70 years old and more. For the calculation of standardized mortality rates, the corrected number of deaths was used.

The proportional mortality of the basic cause of death in relation to the total number of deaths by LTA was calculated as the percentage of deaths of CTAT or other means of transport according to age groups and genders. The proportion of deaths of CTAT who had head trauma identified as a consequential cause of death was calculated, being defined as intermediate or immediate cause, described in Part I, lines $\mathrm{a}, \mathrm{b}, \mathrm{c}$ or $\mathrm{d}$ of DO, and excluding the basic cause of death.

The tendencies of the standardized mortality rates in Brazil and regions were estimated by the simple linear regression. The conjectures for the use of this statistics were measured and tendencies were considered to be statistically significant when $\mathrm{p} \leq 0.05$. The analyses were made with the assistance of the Stata, version 10, and Microsoft Excel.

This study was conducted exclusively with data from the Mortality Information System (SIM), of public access, without identifying the subjects and observing the principles of ethics in research involving human beings, therefore, the appreciation of an ethics committee was dismissed.

\section{Results}

In the period of $2000-2010$, after the correction for sub-register, 32,422 deaths of cyclists injured in transport accidents (CTAT) were identified in Brazil. In the same period, 390,767 deaths caused by land transport accidents (LTA) were registered. Deaths of CTAT corresponded to $9.3 \%$ of the total number of deaths caused by LTA. In 2000, the deaths of CTAT corresponded to $8.9 \%$ of the total number of deaths caused by LTA ( $\mathrm{n}=2,588)$, while in 2010 it was $7.3 \%$ of this total $(n=3,177)$ (Figure 1). In the period of 2000-2010, there was increasing participation of deaths of motorcyclists, from 14.6 to $28.8 \%$, and car occupants, of 24.2 to $24.7 \%$. On the other hand, there was

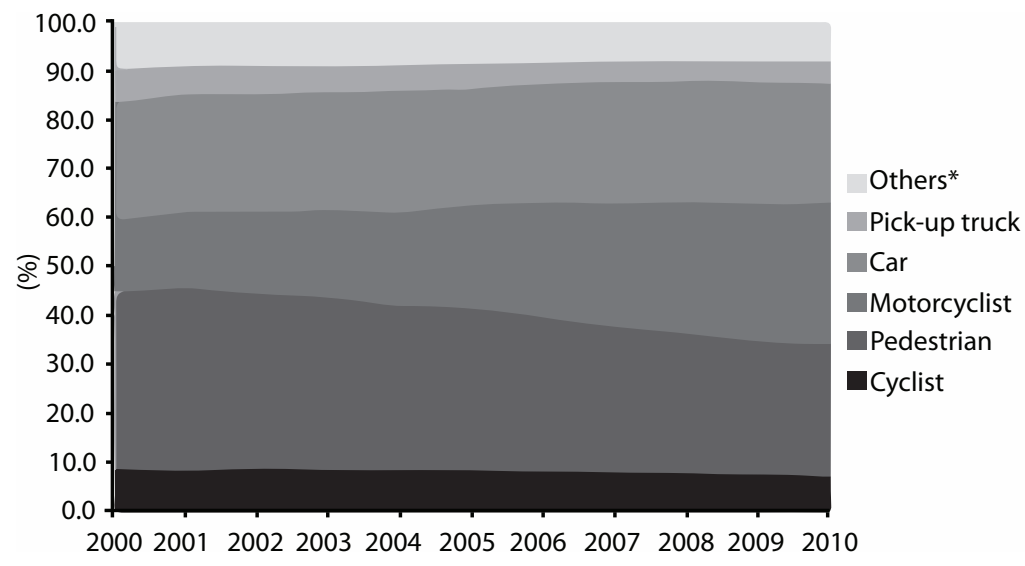

*Three-wheeled vehicle, heavy traffic vehicle, bus and other land transport accidents.

*Triciclo, transporte pesado, ônibus e outros acidentes de transporte terrestre.

Figure 1 - Proportional mortality (\%) according to cause of death in relation to the total number of deaths by traffic accidents. Brazil, 2000 to 2010.

Figura 1 - Mortalidade proporcional (\%) segundo causa básica do óbito em relação ao total de óbitos por acidentes de transporte terrestre. Brasil, 2000 a 2010. 
reduced participation of deaths of pedestrians, from 36.0 to $26.8 \%$.

In Brazil, there was increased crude mortality rate of CTAT, from 15.7 deaths per million inhabitants, in the triennium 2000-2002, to 16.1 , in the triennium 20082010 , with positive variation of $2.3 \%$. In both trienniums, the frequency of deaths of CTAT was higher among men, among people age 20 to 49 years old, white or yellow, with low schooling. More frequent deaths occurred on Saturdays and Sundays, with relatively homogeneous distribution during the entire year. The metropolis presented the lowest risks of deaths of CTAT, followed by small cities 2 (Table 1 ).

In both trienniums, the risk of death of CTAT estimated by the crude mortality rate was about five times higher among men in relation to women (Table 1). This risk increases with age, reaching values close to 20 deaths per million inhabitants in the age grouop of 20 to 29 years old, and these values are maintained to older ages (Figure 2).

After investigating the consequential causes of deaths of CTAT, it was observed that in $42.8 \%$ there was head trauma (data not shown). The annual number of deaths of CTAT in Brazil increased from 2,588, in 2000 , to 3,177 , in 2010 , with positive variation of $22.8 \%$. In the period of $2000-2010$, there were in average 2,947 deaths a year. In 2010, there were in average 264.8 deaths of CTAT a month, or 8.8 a day. There was stability in standardized mortality rates in the period of 2000 to 2010 (15.4 deaths and 15.9 deaths per million inhabitants, respectively). The Northeast presented more expressive increase in standardized rates (from 9.8 to 16.0 deaths), with statistically significant tendency, as well as the North region. The Center-West region presented stable and higher rates than the other regions, in all of the observed years (23.4 deaths per million inhabitants, in 2010). In the Southeast region, there was statistically significant reduction of rates (15.1 and 13.2, in 2000 and 2010, respectively). In the South region, there was statistically significant reduction (24.2 and 20.9 deaths per million inhabitants, in the same years). In 2010, the highest crude and standardized mortality rates of CTAT were registered in Center-West (22.5 and 23.4, respectively) and South regions (21.9 and 20.9, respectively) (Table 2).

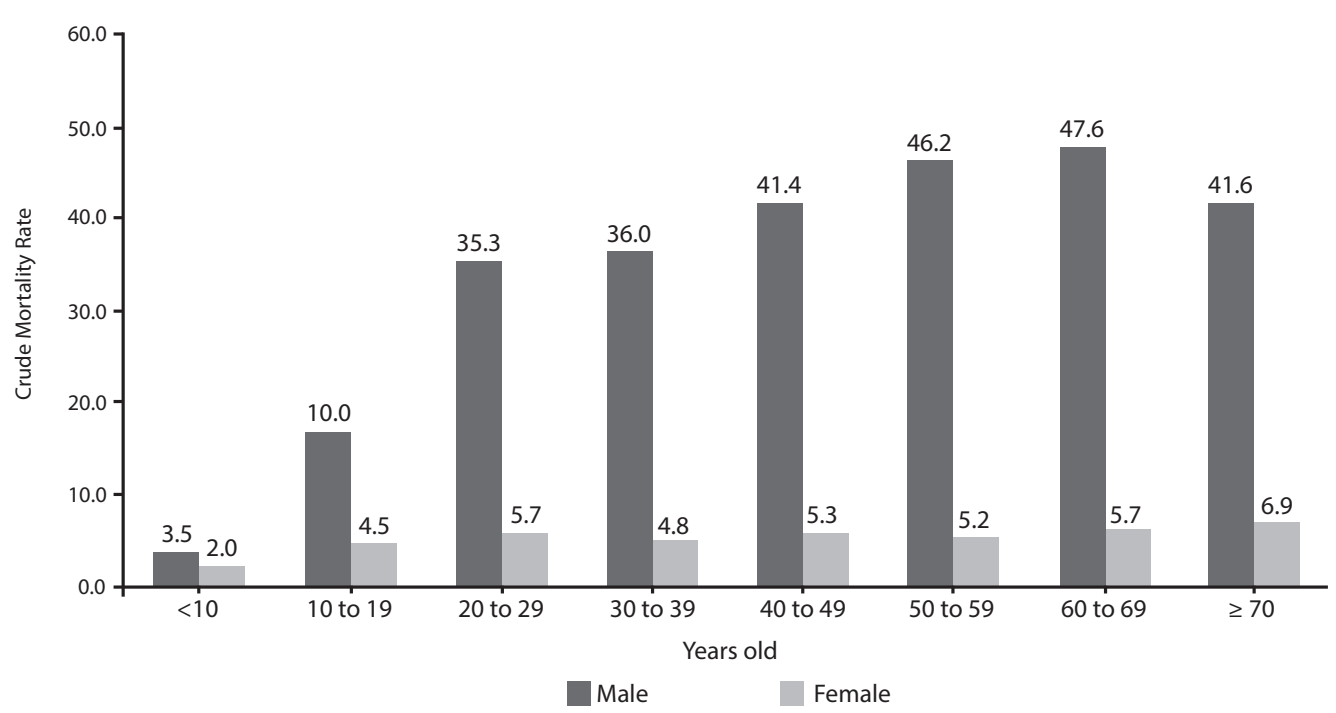

Figure 2 - Crude mortality rate of cyclists injured in transport accidents (deaths per million inhabitants), according to age groups and sex, total for the period $2000-2010$.

Figura 2 - Taxa bruta de mortalidade de ciclistas traumatizados em acidentes de transporte (óbitos por milhão de habitantes), segundo faixas etárias e sexo, total do período 2000 - 2010. 
Table 1 - Number of deaths of cyclists injured in transport accidents, proportion (\%) and crude mortality rates (per million inhabitants) according to characteristics of the victim and of the occurrence. Brazil, 2000 to 2010.

Tabela 1 - Número de óbitos de ciclistas traumatizados em acidentes de transporte, proporção (\%) e taxas de mortalidade brutas (por milhão de habitantes) segundo características das vítimas e da ocorrência. Brasil, 2000 a 2010.

\begin{tabular}{|c|c|c|c|c|c|c|c|c|c|}
\hline \multirow{4}{*}{ Variables } & \multicolumn{3}{|c|}{ Absolute number } & \multicolumn{3}{|c|}{ Proportional mortality (\%) } & \multicolumn{3}{|c|}{ Mortality rate } \\
\hline & 2000 & 2008 & 2000 & 2000 & 2008 & 2000 & 2000 & 2008 & 2000 \\
\hline & $\mathrm{a}$ & $\mathrm{a}$ & $\mathrm{a}$ & $\mathrm{a}$ & $a$ & $a$ & $\mathrm{a}$ & $\mathrm{a}$ & $a$ \\
\hline & 2002 & 2010 & 2010 & 2002 & 2010 & 2010 & 2002 & 2010 & 2010 \\
\hline \multicolumn{10}{|l|}{ Gender } \\
\hline Male & 6.861 & 7.905 & 27.685 & 84.5 & 86.0 & 85.4 & 27.0 & 28.2 & 28.1 \\
\hline Female & 1.257 & 1.292 & 4.728 & 15.5 & 14.0 & 14.6 & 4.8 & 4.4 & 4.6 \\
\hline \multicolumn{10}{|l|}{ Age group (years) } \\
\hline$<10$ & 304 & 221 & 1.023 & 3.8 & 2.4 & 3.2 & 3.0 & 2.3 & 2.9 \\
\hline 10 to 19 & 1.176 & 1.000 & 4.182 & 14.5 & 10.9 & 13.0 & 10.9 & 9.9 & 10.8 \\
\hline 20 to 29 & 1.930 & 1.939 & 7.347 & 23.9 & 21.2 & 22.8 & 21.1 & 18.5 & 20.4 \\
\hline 30 to 39 & 1.607 & 1.639 & 6.023 & 19.9 & 17.9 & 18.7 & 20.9 & 18.8 & 19.9 \\
\hline 30 to 49 & 1.286 & 1.596 & 5.402 & 15.9 & 17.4 & 16.7 & 21.9 & 21.9 & 22.1 \\
\hline 50 to 59 & 863 & 1.271 & 3.986 & 10.7 & 13.9 & 12.3 & 22.7 & 24.0 & 24.0 \\
\hline 60 to 69 & 561 & 874 & 2.560 & 6.9 & 9.5 & 7.9 & 22.5 & 27.1 & 24.7 \\
\hline$\geq 70$ & 357 & 618 & 1.765 & 4.4 & 6.8 & 5.5 & 18.5 & 23.3 & 21.0 \\
\hline \multicolumn{10}{|l|}{ Color or ethnicity } \\
\hline $\begin{array}{l}\text { White or yellow } \\
\text { Black or }\end{array}$ & 4.758 & 4.373 & 17.288 & 64.1 & 49.4 & 56.4 & - & - & - \\
\hline $\begin{array}{l}\text { mulatto or } \\
\text { indigenous }\end{array}$ & 2.670 & 4.471 & 13.363 & 35.9 & 50.6 & 43.6 & - & - & - \\
\hline \multicolumn{10}{|l|}{$\begin{array}{l}\text { Schooling } \\
\text { (years of study) }\end{array}$} \\
\hline$\leq 7$ & 3.205 & 4.190 & 13.773 & 47.9 & 53.8 & 51.8 & - & - & - \\
\hline$\geq 8$ & 1.047 & 1.758 & 5.232 & 15.6 & 22.6 & 19.7 & - & - & - \\
\hline Ignored & 2.443 & 1.836 & 7.589 & 36.5 & 23.6 & 28.5 & - & - & - \\
\hline \multicolumn{10}{|l|}{ Size of the City } \\
\hline Small 1 & 1.179 & 1.298 & 4.368 & 14.5 & 14.1 & 13.9 & 20.3 & 18.6 & 18.9 \\
\hline Small 2 & 1.233 & 1.368 & 4.465 & 15.2 & 14.9 & 14.2 & 16.0 & 15.4 & 14.7 \\
\hline Medium & 1.158 & 1.203 & 4.142 & 14.3 & 13.1 & 13.2 & 18.5 & 18.2 & 17.6 \\
\hline Large & 3.054 & 3.851 & 12.801 & 37.6 & 41.9 & 40.8 & 19.9 & 21.0 & 20.5 \\
\hline Metropolis & 1.500 & 1.480 & 5.635 & 18.5 & 16.1 & 17.9 & 13.5 & 11.7 & 12.8 \\
\hline \multicolumn{10}{|l|}{ Weekdays } \\
\hline Monday & 1.051 & 1.260 & 4.284 & 12.9 & 13.7 & 13.2 & - & - & - \\
\hline Tuesday & 955 & 1.060 & 3.764 & 11.8 & 11.5 & 11.6 & - & - & - \\
\hline Wednesday & 897 & 1.129 & 3.802 & 11.0 & 12.3 & 11.7 & - & - & - \\
\hline Thursday & 998 & 1.140 & 4.018 & 12.3 & 12.4 & 12.4 & - & - & - \\
\hline Friday & 1.101 & 1.263 & 4.481 & 13.6 & 13.7 & 13.8 & - & - & - \\
\hline Saturday & 1.468 & 1.574 & 5.662 & 18.1 & 17.1 & 17.5 & - & - & - \\
\hline Sunday & 1.654 & 1.774 & 6.412 & 20.4 & 19.3 & 19.8 & - & - & - \\
\hline $\begin{array}{l}\text { Month of } \\
\text { occurrence }\end{array}$ & & & & & & & - & - & - \\
\hline January & 654 & 705 & 2.532 & 8.1 & 7.7 & 7.8 & - & - & - \\
\hline February & 615 & 678 & 2.442 & 7.6 & 7.4 & 7.5 & - & - & - \\
\hline March & 657 & 807 & 2.685 & 8.1 & 8.8 & 8.3 & - & - & - \\
\hline April & 699 & 705 & 2.681 & 8.6 & 7.7 & 8.3 & - & - & - \\
\hline May & 682 & 822 & 2.789 & 8.4 & 8.9 & 8.6 & - & - & - \\
\hline June & 643 & 779 & 2.726 & 7.9 & 8.5 & 8.4 & - & - & - \\
\hline July & 737 & 764 & 2.805 & 9.1 & 8.3 & 8.7 & - & - & - \\
\hline August & 665 & 818 & 2.785 & 8.2 & 8.9 & 8.6 & - & - & - \\
\hline September & 694 & 763 & 2.714 & 8.5 & 8.3 & 8.4 & - & - & - \\
\hline October & 731 & 781 & 2.786 & 9.0 & 8.5 & 8.6 & - & - & - \\
\hline November & 629 & 740 & 2.588 & 7.7 & 8.0 & 8.0 & - & - & - \\
\hline December & 718 & 838 & 2.889 & 8.8 & 9.1 & 8.9 & - & - & - \\
\hline Brazil & 8.124 & 9.200 & 32.422 & - & - & - & 15.7 & 16.1 & 16.2 \\
\hline
\end{tabular}


Table 2 - Number of deaths, crude and standardized* mortality rates of cyclists injured in transport accidents (per million inhabitants). Brazil and regions, 2000 - 2010.

Tabela 2 - Número de óbitos, taxas brutas e padronizadas* de mortalidade de ciclistas traumatizados em acidentes de transporte (por milhão de habitantes). Brasil e regiões, 2000 - 2010.

\begin{tabular}{|c|c|c|c|c|c|c|c|c|c|c|c|c|}
\hline & 2000 & 2001 & 2002 & 2003 & 2004 & 2005 & 2006 & 2007 & 2008 & 2009 & 2010 & Trend** \\
\hline \multicolumn{13}{|l|}{ North } \\
\hline $\mathrm{n}$ & 147 & 154 & 200 & 184 & 190 & 229 & 220 & 225 & 258 & 230 & 242 & - \\
\hline Crude rate & 10.2 & 10.6 & 12.9 & 11.9 & 11.8 & 13.9 & 13.2 & 15.5 & 15.5 & 13.4 & 13.7 & - \\
\hline Standardized rate & 12.1 & 12.7 & 14.7 & 14.2 & 14.1 & 16.6 & 15.8 & 18.0 & 18.0 & 15.6 & 15.4 & $B=-0.375(p=0.008)$ \\
\hline \multicolumn{13}{|l|}{ Northeast } \\
\hline $\mathrm{n}$ & 453 & 444 & 524 & 478 & 471 & 537 & 585 & 653 & 653 & 668 & 854 & - \\
\hline Crude rate & 8.9 & 8.5 & 10.0 & 9.1 & 8.8 & 9.9 & 10.7 & 11.8 & 11.8 & 11.9 & 15.6 & - \\
\hline Standardized rate & 9.8 & 9.4 & 10.8 & 10.0 & 9.5 & 10.7 & 11.7 & 12.4 & 12.4 & 12.6 & 16.0 & $ß=0.503(p<0.001)$ \\
\hline \multicolumn{13}{|l|}{ Southeast } \\
\hline $\mathrm{n}$ & 1.115 & 1.170 & 1.199 & 1.232 & 1.288 & 1.301 & 1.236 & 1.226 & 1.104 & 1.104 & 1.138 & - \\
\hline Crude rate & 15.1 & 15.7 & 15.9 & 16.1 & 16.5 & 16.3 & 15.3 & 15.0 & 13.4 & 13.4 & 13.8 & - \\
\hline Standardized rate & 15.1 & 15.7 & 15.8 & 15.9 & 16.3 & 16.1 & 15.1 & 14.7 & 14.0 & 13.0 & 13.2 & $B=-0.266(p=0.005)$ \\
\hline \multicolumn{13}{|l|}{ South } \\
\hline $\mathrm{n}$ & 606 & 593 & 705 & 711 & 728 & 672 & 654 & 616 & 632 & 595 & 612 & - \\
\hline Crude rate & 23.8 & 22.9 & 27.0 & 26.9 & 26.8 & 24.5 & 23.5 & 21.7 & 22.6 & 21.0 & 21.9 & - \\
\hline Standardized rate & 24.2 & 23.2 & 27.4 & 27.0 & 26.9 & 24.6 & 23.5 & 21.3 & 22.0 & 20.3 & 20.9 & $B=-0.537(p=0.015)$ \\
\hline \multicolumn{13}{|l|}{ Center-West } \\
\hline $\mathrm{n}$ & 267 & 252 & 296 & 274 & 328 & 374 & 337 & 366 & 363 & 354 & 331 & - \\
\hline Crude rate & 21.6 & 19.9 & 23.6 & 20.9 & 24.4 & 27.8 & 24.0 & 25.8 & 22.5 & 24.2 & 22.5 & - \\
\hline Standardized rate & 22.8 & 22.1 & 26.3 & 23.0 & 26.8 & 30.7 & 25.5 & 27.4 & 27.0 & 26.0 & 23.4 & $ß=0.256(p=0.316)$ \\
\hline \multicolumn{13}{|l|}{ Brazil } \\
\hline $\mathrm{n}$ & 2.588 & 2.613 & 2.924 & 2.879 & 3.005 & 3.113 & 3.032 & 3.068 & 3.072 & 2.951 & 3.177 & - \\
\hline Crude rate & 14.7 & 14.7 & 16.2 & 15.7 & 16.1 & 16.4 & 15.7 & 15.7 & 15.7 & 14.9 & 16.1 & - \\
\hline Standardized rate & 15.3 & 15.3 & 16.8 & 16.3 & 16.6 & 16.9 & 16.1 & 15.9 & 15.8 & 15.0 & 15.9 & $\beta=-0.222(p=0.725)$ \\
\hline
\end{tabular}

${ }^{*}$ Age-standardized mortality rates through direct metod, using WHO world standard population; **Trend refers to standardized mortality rates. *Taxas de mortalidade padronizadas por idade pelo método direto, tendo como padrão a população mundial padrão da OMS; **Tendência referente à taxa de mortalidade padronizada.

As to the occurrence of deaths of CTAT in the FU, in the period of 2000 to 2010 , Roraima presented the highest standardized mortality rates (65.4 and 42.7 deaths per million inhabitants, respectively). These values are much higher in relation to the mean rates observed in Brazil. In 2010, high rates were also observed in the states of Rondônia (43.4), Amapá (31.2) and Alagoas (29.0). The states that presented remarkable tendencies of increment in the standardized mortality rates of CTAT, per million inhabitants, in the period of 2000-2010, were: Acre (from 2.4 to 24.3), Amapá (from 3.2 to 31.2), Paraíba (from 11.8 to 22.0 ) and Alagoas (from 4.8 to 29.0). On the other hand,

In 2010, Pará, Amazonas and the Federal District presented the lowest standardized mortality rates of CTAT $(7.8 ; 8.3$ and 9.3 deaths per million inhabitants, respectively) (Figure 3). 


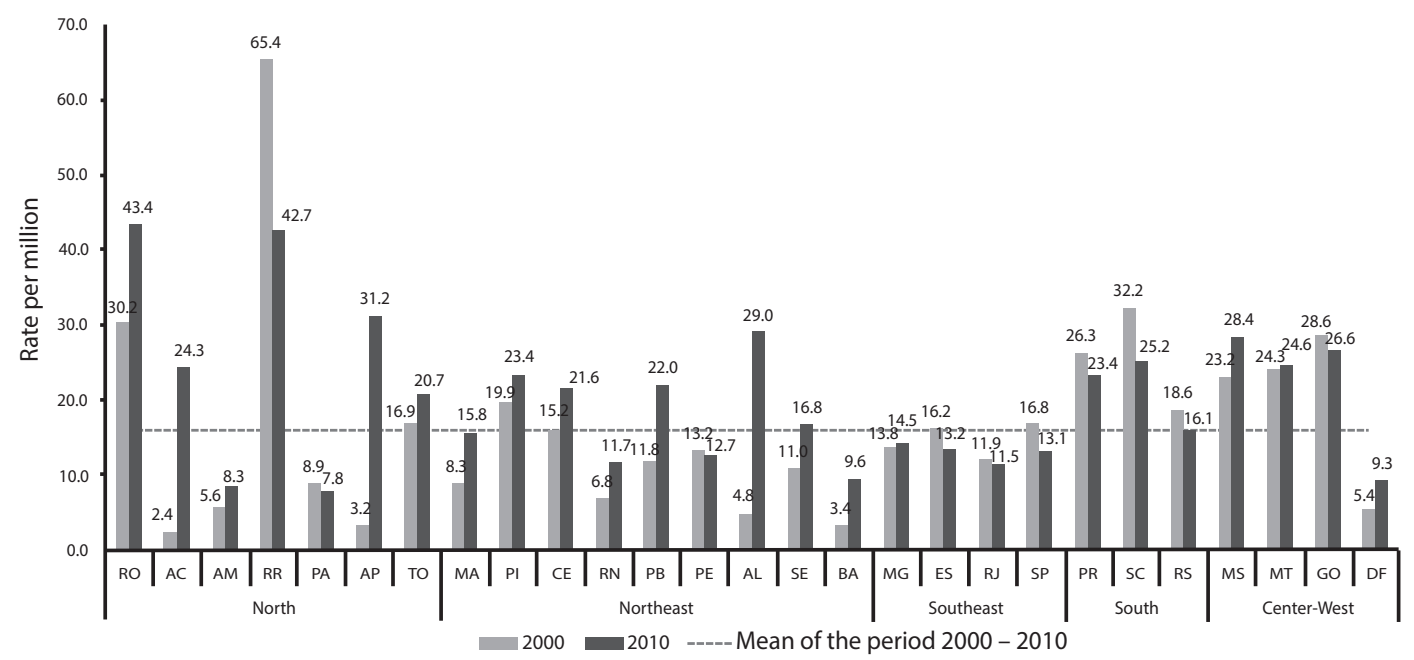

${ }^{*}$ Age-standardized mortality rates through direct metod, using WHO world standard population.

*Taxas de mortalidade padronizadas por idade pelo método direto, tendo como padrão a população mundial padrão da OMS.

Figure 3 - Standardized mortality rates* of cyclists injured in transport accidents (per million inhabitants). States, 2000 and 2010, and Brazil, average for the period 2000 - 2010.

Figura 3 - Taxas padronizadas* de mortalidade de ciclistas traumatizados em acidentes de transporte (por milhão de habitantes). Unidades da Federação, 2000 e 2010, e Brasil, média do período 2000 - 2010.

\section{Discussion}

This study revealed that mortality rates of cyclists injured in transport accidents in Brazil are high, and presented stability in the period of 2000 to 2010 . However, there was increase in the Northeast and North regions, and reduction in the South and Southeast regions. Cyclists took the forth position between fatal victims of transport accidents, after motorcyclists, pedestrians and car occupants. The highest mortality rates of cyclists were observed in the Center-West and South regions. Deaths were concentrated in large cities. The risk of death due to this cause was almost five times higher among men in relation to women. Deaths were more frequent on weekends. The highest mortality rates were observed in the age groups older than 20 years old, and remained high even at older ages.

The structural fragility of bicycles, the differential of speed between bicycles and motorized vehicles and the frequent absence of bicycle paths produce a narrow relationship between these means of transportation in urban regions, thus designing a highly risky scenario to cyclists. These factors, together with the increasing fleet of bicycles and the low adherence to protective equipment among cyclists can be mentioned as explanations to the high rates of mortality of cyclists in Brazil. The Ministry of Cities estimates that the Brazilian bicycle fleet is close to 75 million units, which are mainly used as a mean of transport of workers ${ }^{1}$. In the 1990s, public policies addressed to encourage the use of the bicycle were adopted in some cities ${ }^{10}$. In 1997, the Brazilian Traffic Code ${ }^{11}$ determined the protection to bicycle in urban traffic, including the prediction of a fine to drivers who disrespect the minimum distance of 1.5 meters when passing or surpassing a bicycle. In 2004, the use of the bicycle had new stimulation with the Bicycle Brazil Program².

In this study, the highest mortality rates of cyclists were registered in medium and large cities, which can be explained by the size of bicycle flee and the number of motorized vehicles, as well as by the lack of cycling infrastructure. Even though the major cycling demand is in the suburb, cycling structures are usually in regions that are adjacent to the central area of cities ${ }^{3}$. Traffic accidents are not concentrated in large cities and are not directly related to the size of the city, as in the case of homicies ${ }^{12}$. Even though metropolis have a high absolute number of traffic-related deaths, in relative terms mortality is not as high as in medium and large cities. 
In this study, it was observed that deaths of cyclists were more frequent on weekends, which is in accordance with other studies ${ }^{13}$. This finding can reflect the use of the bicycle for leisure by people who are not so familiar with its risks; it can also be associated with the higher alcohol consumption during weekends ${ }^{14,15}$.

Higher mortality rates were observed in the Center-West and South regions. However, a study conducted with data from the National Household Sample Survey (PNAD), conducted in 2008, revealed that the North and Northeast regions presented the highest proportions of accidents involving bicycles, in relation to all of the transport accidents. In these regions, the importance of the events involving the cyclists can be associated with the frequent use of the bicycle as a mean of transport to work, especially in small cities and in rural areas ${ }^{16}$.

A cross-sectional study conducted in the city of Pelotas, Rio Grande do Sul, with a sample of 1,705 workers aged 15 years old or more, living in the urban zone, revealed that the prevalence of bicycle use was of $17.2 \%$ (95\%CI 15.4 - 19.0). Higher prevalence was found among men, with low schooling and lower economic status. Approximately $6 \%$ of the workers had suffered traffic accidents with body injury in the 12 months prior to the interview ${ }^{17}$.

It is known, however, that bicycle-related accidents present high sub-notification. Another study conducted in Pelotas, which identified all of the victims of traffic accidents from October 1997 to September 1999, revealed that the sub-notification of accidents with cyclists in the police reports was of $33 \%$. Besides, in relation to running over cyclists, the lack of registers of the vehicle in charge was even higher: $47 \%^{13}$.

The VIVA survey (Violence and Accident Surveillance), performed in 2009 in public emergency services of 23 capitals in Brazil and in the Federal District, showed that among the 9,934 assistances due to registered transport accidents, most referred to accidents in which the victim was riding a motorcycle (50.9\%), and a bicycle (18.4\%), being higher than victims who were car occupants $(9.5)^{18}$. Even though the injuries caused to cyclists do not show among the main external causes of death, its relevance is evident in the emergency services.

Besides, the lethality of bicycle-related accidents is high. A study conducted in the city of Pelotas, Rio Grande do Sul, showed that the lethality of pedestrians and cyclists was almost the same, about $5 \%$, higher to that of motorcyclists (3\%) and car occupants $(1.3 \%)^{13}$.

One of the relevant findings of this study was the risk of death among elderly cyclists, in relation to the other age groups. This result allied to the supposition that elderly people are not the main users of this mean of transport confirms the highest lethality of accidents in this population, already described by other studies. A study conducted with victims aged 60 years old or more, who had accidents in 1995, in the urban perimeter of the city of Maringá, Paraná, showed that the incidence of traffic accidents among the elderly was of 329.2 per 100 thousand inhabitants, which is lower in comparison to the other age groups (528.2 per 100 thousand inhabitants) ${ }^{19}$. However, the coefficient of lethality was three times higher among the elderly in relation to victims aged less than 60 years old $(10.3 \%$ and $3.4 \%$, respectively), which expresses that elderly people are more vulnerable to more severe traumas. Still, $13 \%$ of the elderly who were victims of transport accidents were cyclists, only after pedestrians (52\%). The authors attributed the high occurrence of bicycle accidents to how frequently this vehicle is used as a mean of transport by the elderly in the city ${ }^{19}$. A study conducted in England, with data from 2007 - 2009, calculated the risk of hospitalizations and deaths by accidents per hours of use of different means of transport and according to different age groups. Male cyclists aged 70 years old or more constituted the group with higher risk ${ }^{20}$.

As limitations of this study, those related to the use of secondary data from SIM stand out, despite the amplification of coverage and the improved quality of information in this system. In the period of 2000-2010, there was reduction of deaths caused by LTA with nonspecified cause, from $37 \%$ to $23 \%$. However, in 2010 , the type of vehicle or the mean of 
transport of victims of almost one fourth of deaths caused by LTA were not known. Therefore, it was chosen to proportionally redistribute these causes of death, aiming to correct, even if partially, sub-registration. However, no correction was conducted for deaths by ill-defined causes. Therefore, it is possible that there is residual underestimation of mortality. Besides, inequalities in the quality and coverage of SIM between the studied years and regions and FU can damage the comparison of indicators between different moments in time and geographic areas. Another limitation is related to the denominator used to calculate mortality rates. The total population was used as denominator, since the number of cyclists was unknown, as well as the distance or duration of the routes taken with bicycles, which would have led to more accurate indicators. Considering the possible increased of the bicycle fleet in the studied period, and the unequal distribution of populations in the different states and regions of Brazil, the mortality rates could be under or overestimated in relation to this alternative denominator. Besides, other denominators could be used to estimate the risk of death and to allow the comparison with other means of transport ${ }^{20}$.

According to a document by SeMob, the bicycle is considered to be "transparent" or "invisible" not only because of its physical simplicity, but also by the low impact to the environment. The bicycle requires reduced infrastructure for circulation and parking, once it demands little space. Besides, it generates no noise or pollutant emission. Despite that, many users of the streets only see the bicycles when considering they "disturb traffic", without considering their benefits ${ }^{1}$. Besides, the bicycle also brings benefits to the health of its users, once it leads to the practice of physical activity. Vigitel (surveillance of risk factors and protection for chronic diseases by telephonic survey), conducted in $2006^{21}$, revealed that riding a bicycle is a frequently used physical activity for leisure, losing only to walking, soccer, weight lifting and running.

The Brazilian Program of Bicycle Mobility, or Bicycle Brazil Program (PBB), states that the inclusion of the bicycle in urban dislocations should be approached in urban mobility policies as a way of social inclusion, besides reducing and eliminating pollutant agents and improving the health of the population ${ }^{1}$. Among its objectives, stimulating city governments to establish cycling systems and a creating set of actions to guarantee the safety of the cyclists in urban dislocations stand out ${ }^{2}$. The insertion of the bicycle in the current transport systems should be encouraged, with the construction of bicycle paths and bicycle lanes, and the inclusion of the modern concept of cyclable routes, which are shared traffic routes adapted for the safe use of the bicycle ${ }^{1}$. A literature review identified the construction of exclusive spaces for the circulation of bicycles (bicycle paths and bicycle lanes) as the main suggestion to increase safety ${ }^{22}$. Aiming at the reduction of deaths among cyclists, besides the investments in infrastructure, the use of protective equipment should be encouraged. The mandatory equipment for bicycles with rim superior to 20 is: rear view mirror on the left side, attached to the handlebars with no support rod; bell; night reflection signaling, with visibility of at least 30 meters, in the front, in the back, on the sides and on the pedals ${ }^{23}$.

A study conducted in Pelotas, Rio Grande do Sul, showed that less than $1 \%$ of the bicycles had the protective equipment required by the Brazilian Traffic Code, and that $15 \%$ had no brakes $^{24}$. However, a community intervention to prevent traffic accidents among working cyclists did not have any impact on the occurrence of accidents. The authors attributed this finding to the lack of interest in safety from the cyclists and to the conditions of the paths and the traffic ${ }^{17}$. An important matter is that the helmet is not mandatory protective equipment for cyclists, according to Brazilian legislation ${ }^{23}$. Nonetheless, a systematic review of the Cochrane Collaboration, including controlled studies, showed that the use of helmets promoted a $63 \%$ to $88 \%$ reduction in the risk of head or brain trauma, and a $65 \%$ reduction in the risk of trauma to the upper and mid thirds of the face $\mathrm{e}^{25}$.

The use of helmets by cyclists is mandatory in several countries. A study conducted 
in Victoria, Australia, demonstrated that the number of head traumas reduced $70 \%$ two years after the use of the helmet became mandatory by law, in 1990. There was also a $28 \%$ reduction in the number of deaths of cyclists ${ }^{26}$. A study conducted in Ontario, Canada, revealed that the mortality rate of cyclists aged from 1 to 15 years old presented a 55\% reduction after a similar law was established, in $1995^{27}$.

In this study, it was observed that some type of head trauma was involved in more than $40 \%$ of deaths among cyclists, which is in accordance with another study ${ }^{28}$. This finding can be strongly related to the low adherence to protective equipment, especially the helmet. Facing this fact, the use of helmets by cyclists is strongly recommended. Such resistance is known due to the cost of the helmet, inconvenience (discomfort, heat, among others), or low social acceptance in certain groups ${ }^{29}$. In order to favor the adherence to this recommendation, it is especially suggested to lower the price of this product, aiming at the reduction of its cost in order to make the product more accessible, since this initiative would have great impact on the adherence to this practice. Another suggestion is the connection between the sale of the helmet to the sale of the bicycle, so that all cyclists already receive the helmet when they acquire a new bicycle. The proper regulation and supervision as to the quality of this product are also necessary, as well as the implementation of educational measures.

In Brazil, legal measures addressed to traffic safety should be emphasized, which had an important impact on the reduction of deaths caused by transport accidents ${ }^{30,31}$ : the National Traffic Code $(1998)^{1}$, Lei Seca (law that forbids drinking and driving) (2008) ${ }^{32}$, and Lei da Cadeirinha (law that established the mandatory use of child restraining devices in cars) ${ }^{33}$. The high mortality of cyclists revealed in this study points to the need for the measures in these determinations, especially in the National Traffic Code and in Lei Seca, to be fulfilled. Therefore, not only educational actions and encouragement to the use of protective equipment is recommended, but also the establishemnt of rigorous and constant control.

\section{References}

1. Brasil. Ministério das Cidades, Secretaria Nacional de Transporte e da Mobilidade Humana. Programa Bicicleta Brasil. Programa Brasileiro de Mobilidade por Bicicleta. Brasília (DF); 2007.

2. Brasil. Ministério das Cidades. Portaria no 399, de 22 de setembro de 2004. 2004.

3. Feder M, Moscarelli F, Lopes SB. Considerações sobre o uso da bicicleta em Porto Alegre a partir da análise dos acidentes com vítimas fatais. Anais do $16^{\circ}$ Congresso Brasileiro de Transporte e Trânsito. Maceió, 2007. Disponível em http://www.cbtu.gov.br/estudos/pesquisa/ antp_16congr/resumos/arquivos/antp2007_21.pdf. (Acessado em 15 de janeiro de 2013).

4. World Health Organization (WHO). 2nd Global Status Report on Road Safety [Internet]. Disponível em: http:// www.who.int/violence_injury_prevention/global_status_ report/flyer_en.pdf. (Acessado em 15 de janeiro de 2013).

5. Organización Panamericana de la Salud. Informe sobre el Estado de la Seguridad Vial en la Región de las Américas. Washington; 2009.

6. Reichenheim ME, De Souza ER, Moraes CL, De Mello Jorge MHP, Da Silva CMFP, De Souza Minayo MC. Violence and injuries in Brazil: the effect, progress made, and challenges ahead. Lancet 2011; 377(9781): 1962-75.
7. Souza MFM, Malta DC, Conceição GMS, Silva MMA Gazal-Carvalho C, Morais Neto OL. Análise descritiva e de tendência de acidentes de transporte terrestre para políticas sociais no Brasil. Epidemiol e Serv Saúde 2007; 16(1): 33-44.

8. Grupo Técnico de Prevenção de Acidentes e Violências. Centro de Vigilância Epidemiológica "Prof. Alexandre Vranjac". Coordenadoria de Controle de Doenças. Secretaria de Estado da Saúde de São Paulo. O impacto dos acidentes e violências nos gastos da saúde. Rev Saúde Pública. 2006; 40(3): 553-6.

9. Ahmad OB, Boschi-Pinto C, Lopez AD, Murray CJ, Lozano R, Inoue M. Age Standardization of Rates: A New WHO Standard; 2001.

10. Affonso NS, Badini C, Gouvea F. Mobilidade e Cidadania. São Paulo: ANTP; 2003.

11. Código de Trânsito Brasileiro. Lei no 9.503, de 23 de setembro de 1997.

12. Confederação Nacional de Municípios (CNM). Estudos técnicos. Mapeamento das Mortes por Acidentes de Trânsito no Brasil. 2009.

13. Barros AJD, Amaral RL, Oliveira MSB, Lima SC, Gonçalves EV. Acidentes de trânsito com vítimas: sub-registro, caracterização e letalidade. Cad Saúde Pública 2003; 19(4): 979-86. 
14. Abreu ÂMM, Lima JMB de, Matos LN, Pillon SC. Uso de álcool em vítimas de acidentes de trânsito: estudo do nível de alcoolemia. Rev Latino-Am Enfermagem 2010;18(spe):513-20.

15. Brasil. Ministério da Saúde (MS). Secretaria de Vigilância em Saúde. Viva: vigilância de violências e acidentes, 2008 e 2009. Brasília : Ministério da Saúde; 2010.

16. Malta DC, Mascarenhas MDM, Bernal RTI, Silva MMA da, Pereira CA, Minayo MC de S, et al. Análise das ocorrências das lesões no trânsito e fatores relacionados segundo resultados da Pesquisa Nacional por Amostra de Domicílios (PNAD) Brasil, 2008. Ciênc Saúde Coletiva 2011;16(9): 3679-87.

17. Bacchieri G, Barros AJD, Santos JV dos, Gonçalves H, Gigante DP. Intervenção comunitária para prevenção de acidentes de trânsito entre trabalhadores ciclistas. Rev Saúde Pública 2010; 44(5): 867-75.

18. Malta DC, Bernal RTI, Mascarenhas MDM, Monteiro RA, Sá NNB de, Andrade SSC de A, et al. Atendimentos por acidentes de transporte em serviços públicos de emergência em 23 capitais e no Distrito Federal - Brasil, 2009. Epidemiol Serv Saúde 2012; 21(1): 31-42.

19. Souza RKT, Soares DFPP, Mathias AF, Andrade OG, Santana RG. Idosos vítimas de acidentes de trânsito: aspectos epidemiológicos e impacto na sua vida cotidiana. Acta Sci Health Sci 2003; 25(1): 19-25.

20. Mindell JS, Leslie D, Wardlaw M. Exposure-based, "like-for-like" assessment of road safety by travel mode using routine health data. Baradaran HR. PLoS ONE 2012; 7(12): e50606.

21. Brasil. Ministério da Saúde. Secretaria de Vigilância em Saúde. Secretaria de Gestão Estratégica e Participativa. Vigitel Brasil 2006: vigilância de fatores de risco e proteção para doenças crônicas por inquérito telefônico. Brasília : Ministério da Saúde; 2007.

22. Bacchieri G, Barros AJD. Acidentes de trânsito no Brasil de 1998 a 2010: muitas mudanças e poucos resultados. Rev Saúde Pública 2011; 45(5): 949-63.

23. Conselho Nacional de Trânsito - CONTRAN. Resolução no 46, de 21 de maio de 1998.
24. Bacchieri G, Gigante DP, Assunção MC. Determinantes e padrões de utilização da bicicleta e acidentes de trânsito sofridos por ciclistas trabalhadores da cidade de Pelotas, Rio Grande do Sul, Brasil. Cad Saúde Pública 2005; 21(5): 1499-508.

25. Thompson DC, Rivara F, Thompson R. Helmets for preventingheadand facial injuries in bicyclists. In: The Cochrane Collaboration, Rivara F. Cochrane Database of Systematic Reviews. Chichester, UK: John Wiley \& Sons, Ltd; 1999.

26. Cameron MH, Vulcan AP, Finch CF, Newstead SV. Mandatory bicycle helmet use following a decade of helmet promotion in Victoria, Australia--an evaluation. Accid Anal Prev 1994; 26(3): 325-37.

27. Wesson DE, Stephens D, Lam K, Parsons D, Spence L, Parkin PC. Trends in pediatric and adult bicycling deaths before and after passage of a bicycle helmet law. Pediatrics 2008; 122(3): 605-10.

28. Powell EC, Tanz RR. Cycling injuries treated in emergency departments: need for bicycle helmets among preschoolers. Arch Pediatr Adolesc Med 2000; 154(11): 1096-100.

29. Graitcer PL, Kellermann AL, Christoffel T. A review of educational and legislative strategies to promote bicycle helmets. Inj Prev 1995; 1(2): 122-9.

30. Garcia LP, Freitas LRS de, Duarte EC. Avaliação preliminar do impacto da Lei da Cadeirinha sobre os óbitos por acidentes de automóveis em menores de dez anos de idade, no Brasil: estudo de séries temporais no período de 2005 a 2011. Epidemiol Serv Saúde 2012; 21(3): 367-74.

31. Malta DC, Soares Filho AM, Montenegro M de MS, Mascarenhas MDM, Silva MMA da, Lima CM, et al. Análise da mortalidade por acidentes de transporte terrestre antes e após a Lei Seca - Brasil, 2007-2009. Epidemiol Serv Saúde 2010; 19(4): 317-28.

32. Brasil. Presidência da República. Casa Civil. Lei no 11.706, de 19 de junho de 2008.

33. Brasil. Conselho Nacional de Trânsito - CONTRAN. Resolução no 277, de 28 de maio de 2008.

Received on: 04/18/13

Final version presented on: 06/25/13 Accepted on: 08/12/13 